\title{
天井面下に拡がる火炎の構造と熱伝達性状 \\ FLAME SIZE AND HEAT TRANSFER CORRELATIONS FOR THE SURFACE BURNING OF A CEILING AND IMPLICATIONS FOR THE STRUCTURE OF CEILING FLAMES
}

\author{
長谷見 雄二*，吉田正志** \\ Yuji HASEMI and Masashi YOSHIDA
}

\begin{abstract}
Flame size and heat flux correlations are obtained by experiments for circular flames beneath an unconfined inert ceiling, and are compared against those for one-dimensional flames in a downward channel. The both correlations have resulted in the proportionality of the area covered by a ceiling flame to heat release rate and the sole dependence of flame heat transfer on the distance from the source normalized by the flame length. Heat release rate per unit flame area is found to be significantly smaller with circular flames than with one-dimensional flames. It suggests a weaker entrainment of ambient air to circular flames than to one-dimensional flames. The weak heat flux from a ceiling flame suggests the importance of the preheating of combustible ceiling by hot gas layer for the fast fire spread generally observed in real and experimental room fires. Dimensional analysis offers a partial explanation for the weaker entrainment in circular ceiling flams than in one-dimensional ones. It also suggests the proportionality of horizontal velocity to the distance from the upstream end of the burning surface, and faster velocity with one-dimensional flames than with circular ones.
\end{abstract}

Keywords: ceiling fire, flame length, heat flux, heat release rate, entrainment 天井火炎、火炎長さ、入射熱、発熱速度、エントレインメント

1.はじめに

室火災が、収納可燃物や壁等の部分的な㜣焼からフラッシュオー バーに至る過程では、天井面下を拡がる火炎が重要な役割を果たす ことが経験的に認められている。従って、天井面下の火炎拡大の機 構を把握し、その制御の可能性を探ることは火災安全工学上、重要 な課題であるが、天井面下の火炎性状に関する実験例は少なく、定 量的な知見としては、床面上のクリブ燃焼による火炎が天井に到達

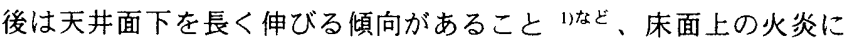
よる天井面の加熱は、連続火炎が天井に届くと著しくなること2).31.4) 等が断片的に報告されているに過ぎない。一方、開口噴出火炎によ る上階延焼の防止対策として庇の効果が広く認められているが、そ れは庇によって開口噴出火炎が上階の開口部から隔離されるととも に庇下面を火炎が流れる間に可燃ガスが消費され、火炎が庇前方か ら噴出してもその長さが短縮されるためと憶測さ扎てきた ${ }^{5) 。 し か ~}$ し、庇が火炎長を短縮するという憶測は、火炎が天井に届くと長く 伸びるという上記の観察と整合しないし、庇のある条件で実施され た模型実験では庇が火炎を短縮する効果はあまり期待できないと指 摘されている6)。こうした現況を見ると、室火災の拡大や庇の延焼 防止効果を適切に評価するには、天井面下の火炎性状が何にどのよ うに支配されているかを解明する必要が大きいと考えられる。
これまで広く研究されてきた床面上の火源や壁面の燃焼に由来す る火炎の性状は、燃焼面を噴出する燃料気体の慣性と火炎の浮力に 支配され、Froude 数又はそれと同等の力学的意味を持つ無次元発 熱速度 Q*等で整理できるという考え方がほぼ確立されている71.87.99。 しかし、天井面下を流れる火炎については少なくとも浮力が運動に 直接関係するわけではないから、既往の火炎モデルの考え方をその まま天井火炎に適用するのが適当とは思われない。天井面下の火炎 に関する上述の数編の研究 23. 3). 4) で主な関心の対象としているのは、 床上火源からの火炎や熱気流が天井に衝乫した時の天井の加熱性状 や天井面下の温度分布であって、報告された天井面下の火炎の拡が り自体はさほど顕著ではない。火災時に火炎が天井や庇の下を流机 るまでには様々な経過が考えられ、天井面や庇の下に単独で火炎が 存在するという状況は想像しにくいものであるが、天井面下を水平 に流れる火炎が他の場合と機構的に異なると想像される以上、天井 面に火炎が拡がる段階での火炎伝播や火炎から天井や床上の可然物 への加熱性状を解明するためには、天井面下に単独で火炎が存在す る条件を人工的に作り出した実験が必要と考えられる。

さて、天井面下の火炎性状において、火災拡大に対する関心から 見て重要なのは、火炎から天井面への入射熱分布と天井面下に拡が る火炎の長さや面積である。即ち、可燃天井面では、火炎伝播の方
* 早稲田大学理工学部建築学科 教授. 工博

** 国土交通省国土技術政策総合研究所建築研究部 主任研究宫
Prof., Department of Architecture, Waseda University, Dr. Eng.

National Institute for Land and Infrastructure Management, MLIT 
向が浮力による対流と方向が一致した順流火炎伝播となるため、火 炎による天井面入射熱は火炎伝播速度を支配する基本的な要素であ り、火炎長さ・面積は、天井の未燃表面の予熱だけでなく、開口部 からの火炎の溢出の可能性や床上の家具等の収納可燃物を放射加熱 して着火に至らしめる加熱源としての性質を端的に表すものである。

筆者らは、既報 ${ }^{10)}$ で、模型規模の不燃材料製天井面に下向きに 長方形の拡散型バーナーを装着し、バーナー幅と同じ幅で両側に垂 れ壁を設けて火炎の流㧈を一方向に制限した状態で純粋な天井火炎 をつくりだし、火炎長さ・天井面熱伝達と発熱速度の関係を求めて、 火炎長さが単位幅当たり発熱速度にほぼ正確に比例すること、天井 面入射熱が火炎長さで無次元化した距離の関数となり、接炎部では 入射熱が壁面上の火炎等よりも小さくなること等を明らかにした。 床上の火源からの乱流拡散火炎では、高さごとの燃焼速度が、その 高さで巻き込ま扟る酸素量に比例するという事実を敷衍すると、こ れは、天井火炎では、燃焼に供さ机る空気(酸素)の巻き込みが火炎 下面で一様になっていて燃焼速度も水平方向の位置によらず一様で あることを示晙している。床面上の火炎では空気の巻き込み量も燃 焼速度も高さによって变化するのとは大きく異なっており、この特 質は天井火炎を特徵づけるものと考元ら扎はするが、天井火炎が一 万向に流㧈るという条件は室火災の様態としては些か特殊で、この 条件で得られた結論が天井火炎一般を代表し得るかについては疑問 なしとしない。そこで、本研究では、既報と同じ装置に筒形の拡散 型バーナーを下向きに装着し、既報とは対照的な様態として火炎が 天井面下を放射状に拡がる条件をつくりだして、火炎面の半径、天 井面熱伝達分布と燃料供給量・発熱速度との関係を調べ、一方向に 流㧈る火炎との比較を行ったうえ、実駼結果の主な特徵を流㧈の基 礎方程式に代入して天井火炎の構造を考察した。

\section{2.実験方法}

Figure 1 に示寸実験装置に一辺 $1820 \mathrm{~mm}$ 厚さ $12 \mathrm{~mm}$ の正方形の無 機質瀻維板(ハーライトボード)二枚張りを天井として取り付け、そ の対角線の交点に筒型の鋼板製拡散型バーナーを下向きに、燃料噴 出面が天井下面と揃うように装着した。天井端部には、垂れ壁等は 設けなかった。また、バーナーは内径 $90 \mathrm{~mm}$ と $160 \mathrm{~mm} の 2$ 種類の ものを作成して噴出面をステンレス網で覆い、バーナー内部に直径 約 $5 \mathrm{~mm}$ の磁器球を充填した。燃料は燃料用ブロハンを使用した。 予備実験では完全燃焼を仮定してガス供給量から計算した発熱速度 (以後、公称発熱量(nominal heat release rate)という)がほぼ 100kW で 火炎先端が天井端部から溢れたため、火炎面積を求める実験は、公 称発熱量 $5.0 \mathrm{~kW} \sim 80 \mathrm{~kW}$ の範囲で行った。

天井面には直径 $15 \mathrm{~mm}$ の円筒型の Schmidt-Boelter 型熱流計(測定 レンジ $100 \mathrm{~kW} / \mathrm{m}^{2}$ )を天井面対角線上に下向きに 10 箇所に装着して 入射熱を測定した。燃料供給速度はガスフローメータでモニタし、 火炎形状をディジタルビデオで下方から撮影記録した。火炎寸法は、 予め天井面にバーナー中心から一定間隔で同心円を描いておき、ビ デオの記録映像から同一の観察者が目視で 1 秒毎に読みとり、1 分 間の平均を報告値とした。従って火炎長の報告值は、従来の火炎実 験における火炎片長さに対応する。更に、装置全体を一辺 $3.0 \mathrm{~m}$ の 集煙フードの下に置いて、排気ダクト内で酸素濃度及び煙流量を計 測し、酸素消費法による燃焼発熱測定を行った。集煙量は、予備実
験で煙を可視化し燃焼生成物がフードから漏扎ないように設定した。 この方法で得た燃焼発熱速度は、以後、実効発熱量(effective heat release rate)という。なお、火炎形状は、一方向の天井火炎 ${ }^{101}$ 等に比 べて気流等の外乱や装置の状態に極めて敏感だったため、実験時に は毎回、天井面の水平等を確認したほか、同じ条件で実験を繰り返 し、火炎が正確に円形となっている条件だけを選び出して分析した。 また、気流ハタン、特に火炎の空気の巻き込み性状を観察するため に火炎下方に線香煙をテフロン管で誘引し、簡単な可視化を行った。
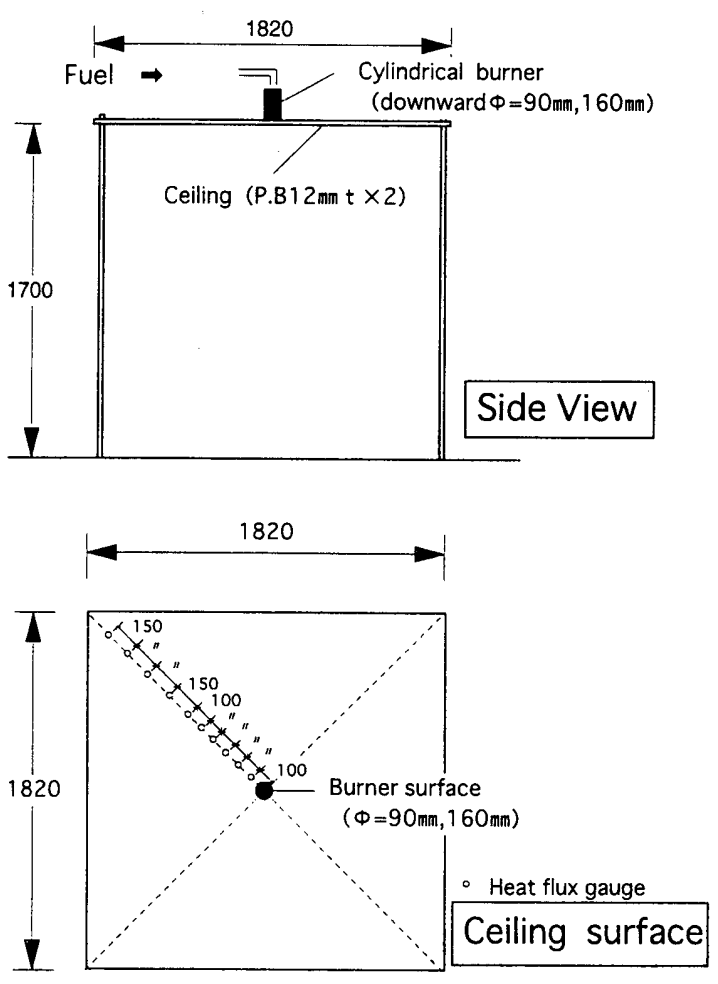

Figure 1 Experimental setup

\section{3.実験結果}

\section{1 概要}

得られた数値デー夕を整理して Table 1 に示す。実験は、公称発 熱量を $5 \mathrm{~kW}$ から順次段階的に大きくして進めたが、公称発熱量 $5 \mathrm{~kW}$ 前後の場合、燃焼は、バーナー噴出口面付近に細胞状に分か㧈た層 流火炎が散在するという様態となった。それ自体は興味深い燃焼現 象であるが、本報告では、天井面下を火炎が放射状に流れることが 観察された公称発熱量 $10 \mathrm{~kW}$ 以上について報告する。また、公称発 熱量と実効発熱量の関係は、Table 1 のように実効発熱量が公称值 の 1/2 以下にまで下回る結果となった。実効発熱量と公称発熱量の 比は燃焼効率を表すから、この結果は、天井火炎では、自由空間の 火炎に比べて燃焼効率が顕著に低下することを示唆している[注 1]。 同様な傾向は、一方向に拡がる天井火炎でも観察されている ${ }^{100}$ 。

拡散型バーナー一のように燃料供給速度を制御できるブール燃焼を 使用した既往の実験のほとんどは、酸素消費法による発熱測定を行 つておらず、発熱速度を公称発熱量で代表させることが慣例化して いるが、燃焼反応が発熱を通じて流れ性状に及ぼす影響は、本来、 実効発熱量で評価した方が合理的なので、本論文で実験結果を発熱 速度との関係で整理する際には、実効発熱量で代表させる。 
Table 1 Summary, digital experimental data

(a) Burner diameter $=90 \mathrm{~mm}$

\begin{tabular}{|c|c|c|c|c|c|c|c|c|c|}
\hline \multicolumn{2}{|c|}{ Nominal HRR(kW) } & 10 & 20 & 30 & 40 & 50 & 60 & 70 & 80 \\
\hline \multicolumn{2}{|c|}{ Effective HRR (kW) } & 3.0 & 8.3 & 10.5 & 15.7 & 16.9 & 25.2 & 31.8 & 38.1 \\
\hline \multicolumn{2}{|c|}{ Flame Radius (m) } & 0.225 & 0.375 & 0.5 & 0.55 & 0.65 & 0.75 & -0.85 & 0.90 \\
\hline \multirow{10}{*}{$\begin{array}{l}\text { Total heat flux } \\
\left(\mathrm{kW} / \mathrm{m}^{2}\right)\end{array}$} & $\mathrm{r}=0.10(\mathrm{~m})$ & 18.9 & 23.7 & 24.8 & 26.3 & 27.0 & 26.7 & 26.6 & 25.0 \\
\hline & 0.20 & 12.1 & 13.3 & 16.3 & 18.4 & 19.1 & 17.8 & 20.6 & 19.8 \\
\hline & 0.30 & 4.5 & 9.6 & 14.0 & 14.7 & 17.2 & 16.4 & 19.8 & 17.5 \\
\hline & 0.40 & 2.3 & 4.5 & 8.5 & 11.6 & 12.1 & 11.1 & 14.5 & 14.7 \\
\hline & 0.50 & 1.6 & 3.0 & 4.7 & 7.7 & 8.6 & 7.3 & 10.1 & 11.5 \\
\hline & 0.60 & 0.9 & 1.9 & 2.9 & 5.0 & 5.6 & 5.1 & 7.9 & 8.6 \\
\hline & 0.75 & 0.6 & 1.3 & 2.1 & 3.6 & 4.0 & 3.6 & 5.3 & 6.3 \\
\hline & 0.90 & 0.3 & 0.7 & 1.2 & 2.1 & 2.3 & 2.6 & 3.2 & 3.7 \\
\hline & 1.05 & 0.2 & 0.6 & 1.0 & 1.8 & 1.9 & 2.3 & 2.6 & 3.2 \\
\hline & 1.20 & 0.2 & 0.3 & 0.6 & 1.3 & 1.4 & 1.6 & 1.8 & 2.2 \\
\hline
\end{tabular}

(b) Burner diameter $=160 \mathrm{~mm}$

\begin{tabular}{|l|r|r|r|r|r|r|r|r|r|}
\hline Nominal HRR $(\mathrm{kW})$ & 10 & 20 & 30 & 40 & 50 & 60 & 70 & 80 \\
\hline \multicolumn{2}{|l|}{ Effective HRR $(\mathrm{kW})$} & 6 & 9.2 & 12 & 15.7 & 19.5 & 28.1 & 34.5 & 38.7 \\
\hline Flame Radius $(\mathrm{m})$ & 0.25 & 0.35 & 0.45 & 0.55 & 0.60 & 0.75 & 0.83 & 0.87 \\
\hline $\begin{array}{l}\text { Total heat flux } \\
\left(\mathrm{kW} / \mathrm{m}^{2}\right)\end{array}$ & $\mathrm{r}=0.10(\mathrm{~m})$ & 14.1 & 17.1 & 20.4 & 16.8 & 19.9 & 18.1 & 19.8 & 16.4 \\
\cline { 2 - 9 } & 0.20 & 9.2 & 13.2 & 15.2 & 14.2 & 16.6 & 16.9 & 16.0 & 15.8 \\
\cline { 2 - 9 } & 0.30 & 4.2 & 9.2 & 11.2 & 11.3 & 12.8 & 16.6 & 15.7 & 13.4 \\
\cline { 2 - 9 } & 0.40 & 2.3 & 4.5 & 9.1 & 9.7 & 10.8 & 11.3 & 12.6 & 11.5 \\
\cline { 2 - 9 } & 0.50 & 1.5 & 2.6 & 5.0 & 7.0 & 8.7 & 9.9 & 10.0 & 10.7 \\
\cline { 2 - 9 } & 0.60 & 0.9 & 1.8 & 3.3 & 4.0 & 5.5 & 6.8 & 7.8 & 8.4 \\
\cline { 2 - 8 } & 0.75 & 0.6 & 1.2 & 2.4 & 2.9 & 3.6 & 4.1 & 5.3 & 5.3 \\
\cline { 2 - 8 } & 0.90 & 0.3 & 0.6 & 1.4 & 1.9 & 2.2 & 2.7 & 3.1 & 3.3 \\
\cline { 2 - 8 } & 1.05 & 0.2 & 0.4 & 1.1 & 1.6 & 1.8 & 2.2 & 2.6 & 2.7 \\
\cline { 2 - 8 } & 1.20 & 0.2 & 0.3 & 0.8 & 1.2 & 1.3 & 1.6 & 1.8 & 2.0 \\
\hline
\end{tabular}

\section{2 火炎寸法と実効発熱速度の関係}

火炎面の半径と実効発熱速度の関係を Figure 2 に示す。火炎はい ず犼も天井面下をシート状に円形に拡がり、公称発熱量 $30 \mathrm{~kW}$ 以下 では発熱速度の増加とともにバーナー面直下の火炎の突出が増加し たが、どの実験でも半径方向に火炎厚さが系統的に変化するように は見えなかった。火炎は、下面で乱狆を発生したり波打つような挙 動を示し、中心から離㧈るほど視覚的に希薄になるが、床面上や壁 際の火炎のように周期的に大きく伸縮するということはなかった。 線香煙を使った可視化によると、火炎より下方には火炎に向かうほ ぼ鉛直上方への流れが見られ、天井面に平行な水平方向流れが顕著 に現扎るのは火炎内部に留まるようである。火炎面半径は $\phi=90 \mathrm{~mm}$ のバーナ゙ーの方が $\phi=160 \mathrm{~mm}$ よりやや大きいが、実効発熱量との関 係をみると、Figure 2 のように $\phi=90 \mathrm{~mm}$ に対する曲線は $\phi=160 \mathrm{~mm}$ のそ扎より 2〜3kW 小さい側にあり、発熱速度が大きくなるにつれ て発熱速度毎の火炎半径の差は目立たなくなる。

バーナ一直径が小さい方が火炎が大きいということは、燃料噴出 面が小さい方が火炎への空気の巻き込みが小さくなることを意味し

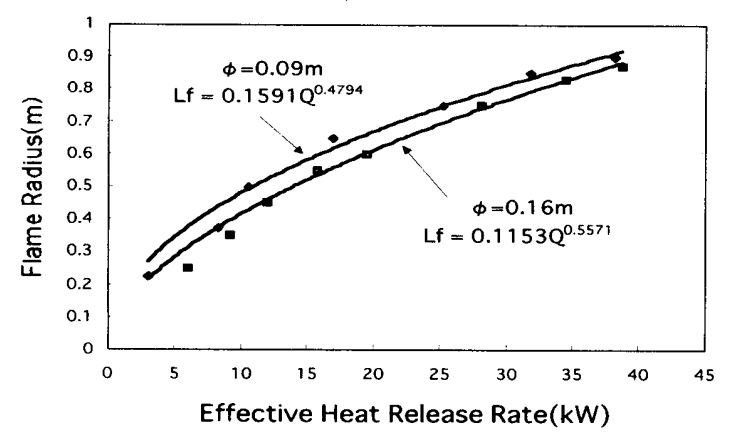

Figure 2 Flame radius vs. effective heat release rate
ているが、そ扎は、少なくとも燃料噴出面近傍の流机性状には燃料 噴出による慣性が影響し、一旦下方に向かった燃料ガスが天井面側 に回り込む時の半径方向流速が、燃料噴出面が小さくて噴出速度が 大きい場合の方が小さくなるためと思わ扟る。発熱速度が小さい領 域ではバーナ一面直下部分の火炎が突出し、Figure2 のように火炎 半径が発熱速度に敏感に反応する傾向を示しているのも同じ理由か らと考えら扎る。Figure 2 によると、火炎半径は、発熱速度が小さ い領域を除いて実効発熱量の平方根にほぼ正確に比例している。こ 扎は、天井面下に円形に拡がる火炎の面積が発熱速度に比例するこ とを意味し、既報で示した一方向の天井火炎の長さが単位幅当たり 発熱速度に比例していた事実と併せて、天井火炎では火炎の流行の 様態にかかわらず、火炎下方からの空気の巻き込みが一様で然焼速 度も一様となることを示している。ここで、今回の実験結果から火 炎面積を計算し、火炎面積と実効発熱量の関係を整理して、既報の 一方向火炎と比較すると、Figure 3 のようになる。火炎面積と実効 燃焼発熱量は、バーナー一毎に比例関係を示し、円形バーナーの実験 結果は互いにかなり近いが、一方向に拡がる火炎に比べると、火炎 面積が顕著に大きいことがわかる。これは、放射状に搪がる天井面 火炎では、一方向に流れる天井面火炎に比べて、火炎の空気の巻き 込みが遙かに弱いことを示している。

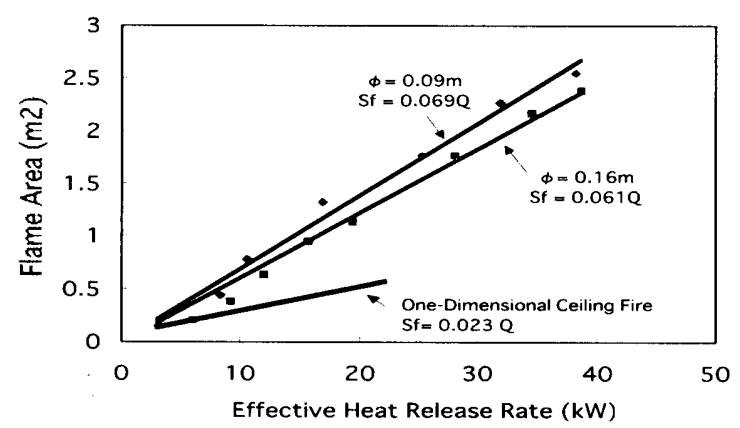

Figure 3 Area of flame sheet vs. effective heat release rate circular and one-way ceiling flames

なお、火炎寸法を測定した最大の公称発熱速度は $80 \mathrm{~kW}$ であるが、 この時の火炎半径はほぼ $0.90 \mathrm{~m}$ 、即ち直径では $1.8 \mathrm{~m}$ と人間の身長 程度に達している。床上の火源から形成される火炎ならば、火炎片 高さでも、公称発熱量 $80 \mathrm{~kW}$ に対しては $1.1 \mathrm{~m}$ 程度にしかならない[注 2]。もともと、床上で上方に伸びる火炎と天井面下の火炎では形状 が全く異なるので規模を直接比較するのは難しいが、天井面下に拡 がる直 $1.8 \mathrm{~m}$ の円形の火炎と床上に筒状に立ち上がる高さ $1.1 \mathrm{~m}$ の 火炎とでは前者の方が大きく見えよう。天井面下では火炎が長く伸 長するという観察記録 りな゙゙が多く見られるのは、このためであろ う。また、室火災において、天井面下を火炎が拡がると床面や作業 面上の未然可燃物等に強い放射を与えて着火させ、フラッシュオー バーを引き起こすが、天井面下を火炎が放射状に拡がる時の火炎面 積が大きくなるという結果は、発熱速度が比較的小さくても、天井 面下に火炎が形成されれれ゙大きな面積の放射熱源を構成し、床面上 の可燃物を加熱し易くなることを意味している。天井面の燃焼制御 は、この意味でも火災拡大防止上、重要な課題である。 


\section{3 天井面入射熱}

壁面上の火炎や一方向に拡がる天井火炎については、表面熱伝達 の分布は、燃料供給領域の気流上流端から測った距離を火炎長さで 割つた無次元長さに支配される事が分かっている ${ }^{101.121 。 そ こ て ゙ 、 ~}$ 本実験で得られた天井表面入射熱を、同様に筒型バーナーの中心か ら各測定点までの距離を火炎半径で割った無次元半径との関係で整 理すると、Figure 4 のようになる。表面入射熱は、火炎の中心付近 では $\phi=90 \mathrm{~mm}$ の方が $160 \mathrm{~mm}$ よりも幾分大きくなっているのを除い て、2つのバーナーの間で良い一致を示し、次のようになった。

$\mathrm{r} / \mathrm{L}_{\mathrm{i}}<0.4 \quad \mathrm{q}_{\mathrm{T}} \fallingdotseq 13.0\left(\mathrm{r} / \mathrm{L}_{\mathrm{i}}\right)^{-1 / 3}$

$0.4 \leqq \mathrm{r} / \mathrm{L}_{\mathrm{f}}<0.7 \quad \mathrm{q}_{\mathrm{T}} \fallingdotseq 7.0\left(\mathrm{r} / \mathrm{L}_{\mathrm{i}}\right)^{-1}$

$0.7 \leqq \mathrm{r} / \mathrm{L}_{\mathrm{f}} \quad \mathrm{q}_{\mathrm{T}} \fallingdotseq 4.5\left(\mathrm{r} / \mathrm{L}_{\mathrm{i}}\right)^{-2.2}$

図には、壁面上の火炎や天井面の一方向火炎について得られた入射 熱分布を整理した結果も記載したが、こ扎より、次のことがわかる。 (1)今回の実験で得ら扎た火炎内部 $\left(r / L_{\mathrm{r}}<1\right)$ の表面入射熱分布は、

一方向天井火炎と似ているが、 $\mathrm{r} / \mathrm{L}_{\mathrm{i}}>1$ では、明らかに一方向天 井火炎より早く減衰する。

(2)壁面上の火炎と比較すると、火炎内部、特に $\mathrm{r} / \mathrm{L}_{\mathrm{i}}<0.7$ では壁面 燃焼による表面入射熱の方が大きいが、 $\mathrm{r} / \mathrm{L}_{\mathrm{i}}>0.7$ では天井火炎の 方が壁面上の火炎よりも入射熱が大きくなる。

表面入射熱が、火炎内部でもほぼ $30 \mathrm{~kW} / \mathrm{m}^{2}$ 以下と小さい值にな っているのは、火災実験等でしばしば観察される天井面燃焼の激し さを思うと意外に感じられるが、天井面下の火炎は、強い浮力のた め下方には拡がりにくく、壁面上の火炎に比べると薄くなる傾向が 強いことがその主な原因であろう。また、一方向火炎の場合を併せ て天井面下の火炎による天井面入射熱がこのように小さけれい゙木質 系内装等では急激な火炎伝播を期待できないにも関わらず、現実の 火災や実大火災実験では可燃性天井面で急激な火炎伝播が起こるの が珍しくないのは、天井火炎自体以外からの加熱、例えば床上の火 源の発熱や天井面燃焼によって形成される煙層からの予熱・加熱が 火炎伝播に重要な役割を果たしていることを示唆するものである。

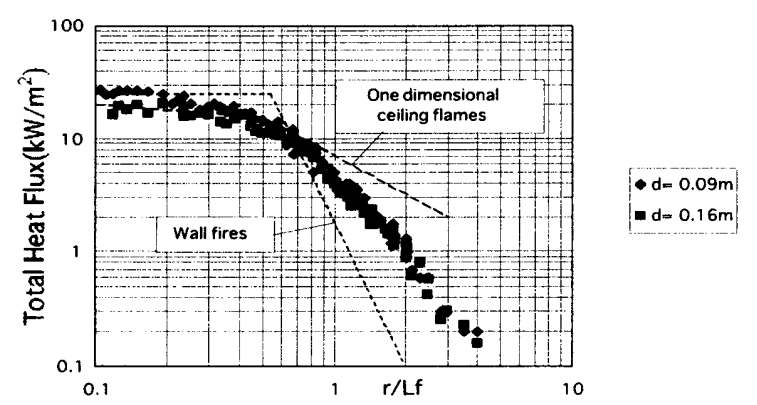

Figure 4 Total heat flux vs. radial distance normalized by flame radius

\section{4.天井面燃焼による火炎の構造の推定}

本実験の主な結果を、運動方程式、エネルギ一方程式に代入し、 天井火炎の構造を推定してみたい。Boussinesq 近似した鈶直方向の 運動方程式及びエネルギー方程式を円筒座標系(但し $z$ は天井面を 原点として下方を正とする。従って浮力項の符号は通常とは逆にな る)で記述すると、 $\frac{\partial r \bar{v}_{r} \bar{v}_{z}}{\partial r}+\frac{\partial r \bar{v}_{z}^{2}}{\partial z}=-r \frac{\partial \bar{p}}{\partial z}-\frac{\partial r \overline{v_{r} v_{z}^{\prime}}}{\partial r}-\frac{\partial r \overline{v_{z}^{\prime 2}}}{\partial z}-r g \beta \bar{\theta}$

$\frac{\partial r \bar{v}_{r} \bar{\theta}}{\partial r}+\frac{\partial r \bar{v}_{z} \bar{\theta}}{\partial z}=-\frac{\partial r \overline{v_{r}^{\prime} \theta^{\prime}}}{\partial r}-\frac{\partial r \overline{v_{z}^{\prime} \theta^{\prime}}}{\partial z}+\frac{r \bar{q}}{\rho C_{p}}$

となるが、こ狄らを

$\frac{d}{d r} \int_{0}^{\infty} \bar{r} \bar{v}_{r} \bar{v}=d z+r\left[\bar{v}_{z}^{2}\right]_{0}^{\infty}=-r[\bar{p}]_{0}^{\infty}-\frac{d}{d r} \int_{0}^{\infty} r \overline{v_{r}^{\prime} v v^{\prime}} d z-r g \beta \int_{0}^{\infty} \bar{\theta} d z$ (3)

$\frac{d}{d r} \int_{0}^{\infty} r \bar{v} \bar{\theta}_{r} \bar{d} d z+r\left[\overline{v_{z}} \overline{\boldsymbol{\theta}}\right]_{0}^{\infty}=-\frac{d}{d r} \int_{0}^{\infty} r \overline{v_{r}^{\prime} \boldsymbol{\theta}^{\prime}} d z+\int_{0}^{\infty} \frac{\overline{r q}}{\rho C_{p}} d z$

となる。但し、 $z=0$ 及び $z \rightarrow \infty て ゙ \overline{v_{z}^{\prime 2}}=\overline{v_{z}^{\prime} \theta^{\prime}}=0$ と仮定した[注 3]。 ここで、観察結果から火炎厚さが一定、火炎下面での下方からの巻 き込み速度も一定と仮定し、水平距離 $\mathrm{r}$ での $v_{n} v_{i}, \theta$ の最大値を 夫々 $A r^{\prime \prime}, B, C$ として、流速・温度分布が、

$\bar{v}_{r}=A \cdot r^{\prime \prime} V_{r}(z), \bar{v}_{z}=B \cdot V_{z}(z), \bar{\theta}=C \cdot \Theta(z)$

で表さ㧈るものとする。 $V_{r}(z), V_{z}(z), \Theta(z)$ は流速・温度の鉛直方向の ブロファイルを表す関数で、1 1 を最大値とする。また、火炎の水平 投影面積当たり発熱速度 $\int_{0}^{\infty} \bar{q} d z$ は実験結果から一定と仮定でき (Figure3によると $\int_{0}^{\infty} \bar{q} d z=15.3 \mathrm{~kW} / \mathrm{m}^{2}$ )、 $z=0$ で $\bar{v}_{i}=0, z \rightarrow \infty$ で $\bar{\theta}=0$ であるから、(3),(4)式は、 $(m+1) r^{m} A B \int_{0}^{\infty} V_{r}(z) V_{z}(z) d z=$

$-r[\bar{p}]_{0}^{\infty}-\frac{d}{d r} \int_{0}^{\infty} r \overline{v_{r}^{\prime} v v^{\prime}} d z-r g \beta C \int_{0}^{\infty} \Theta(z) d z$

$(m+1) r^{m} A C \int_{0}^{\infty} V_{r}(z) \Theta(z) d z=-\frac{d}{d r} \int_{0}^{\infty} \overline{\nu^{\prime} \theta^{\prime}} d z+\frac{r}{\rho C_{p}} \int_{0}^{\infty} \bar{q} d z$

となる。(6),(7)式の左辺及び右辺最右項の定積分は定数となるから、 この等式が成り立つためには、少なくとも $m=1$ となっていなけれ ばならない。即ち、火炎内部の半径方向流速は半径 $r$ に比例して增 加するものと推定できる。ここで、床上の火源からの火炎について は、軸上流速・温度とそれらの水平面分布は相互に関係していたこ とを想起して、天井火炎についても、(5)式に現れる $A, C, V_{r}(z), \Theta(z)$ の間の関係を考察してみたい。まず、実験結果から火炎の水平投影 面積当たり発熱速度が酸素供給速度に比例すると仮定すると、

$\int_{0}^{\infty} \overline{r q} d z=\frac{\Delta H c, O_{2} C\left[O_{2}\right]}{\chi} \frac{d}{d r} \int_{0}^{\infty} r \bar{v} r d z=\frac{2 A r \Delta H c, O_{2} C\left[O_{2}\right]}{\chi} \int_{0}^{\infty} V_{r}(z) d z$

となるから、

$A=\chi \int_{0}^{\infty} \bar{q} d z / 2 \Delta H c, O_{2} C\left[O_{2}\right] \int_{0}^{\infty} V_{r}(z) d z$

火炎内部では、火炎の流㧈方向、即ち水平方向のエネルギ一輸送は、 移流が渦拡散に卓越すると考えられるから、(9)式を(7)式に代入し たうえで、(7)式において、 $m=1$ を代入のうえ、右辺第一項は他の 項より相対的に小さく、無視できるとすると、

$2 r A C \int_{0}^{\infty} V_{r}(z) \Theta(z) d z \cong \frac{\Delta H c, O_{2} C\left[O_{2}\right]}{\rho C_{p} \chi} \frac{d}{d r} \int_{0}^{\infty} r \bar{v} d z$

$=\frac{2 A r \Delta H c, o_{2} C\left[O_{2}\right]}{\rho C_{p} \chi} \int_{0}^{\infty} V_{r}(z) d z$ 
となる。両辺を整理してCについてまとめると、

$C \cong \Delta H c, O_{2} C\left[O_{2}\right] \int_{0}^{\infty} V_{r}(z) d z / \rho C_{n} \chi \int_{0}^{\infty} V_{r}(z) \Theta(z) d z$

但し、(9)、（11)式に含ま扎るハラメータのうち、 $\chi$ は直接には測 定困難である。従って、これらの関係式は、夫々の右辺を計算して $A$ や $C$ を算出するというよりも、むしろ温度・流速の実測值を使 つて、火炎の構造を特徵づけるバラメータである $\chi$ 等を推定する関 係式とみなした方が妥当であろう。 $\int_{0}^{\infty} V_{r}(z) d z, \int_{0}^{\infty} \Theta(z) d z$ は、実験 的に決定すべきハラメータであるが、火炎が厚いほど大きい值を取 るので火炎の厚さを象徵するものである。

因みに、一方向火炎では、直交座標上で、（3）、（4）式に対応 して、下式を誘導出来る。

$\frac{d}{d x} \int_{0}^{\infty} \overline{u w} d z+\left[\bar{w}^{2}\right]_{0}^{\infty}=-[p]_{0}^{\infty}-\frac{d}{d x} \int_{0}^{\infty} \overline{u^{\prime} w^{\prime}} d z-g \beta \int_{0}^{\infty} \bar{\theta} d z$

$\frac{d}{d x} \int_{0}^{\infty} \bar{u} \bar{\theta} d z+[\bar{w} \bar{\theta}]_{0}^{\infty}=-\frac{d}{d x} \int_{0}^{\infty} \overline{w^{\prime} \theta^{\prime}} d z+\int_{0}^{\infty} \frac{\bar{q}}{\rho C_{p}} d z$

ここで、既報 ${ }^{10 \%}$ の観察から(5)式に対応する

$\bar{u}=A^{\prime} \cdot x^{\prime \prime} U(z), \bar{w}=B^{\prime} \cdot W(z), \bar{\theta}=C^{\prime} \cdot \Theta^{\prime}(z)$

なる関数形を仮定し、 $\int_{0}^{\infty} \overline{q d z}=$ 一定(Figure 3 によると $43.5 \mathrm{~kW} / \mathrm{m}^{2}$ ) と すると、 $z=0$ で $\bar{w}=0, z \rightarrow \infty$ で $\bar{w}=\bar{\theta}=0$ であるから、 $n=1$ となつ て、同様に火炎内の水平方向流速は距離に比例して増大寸るという 推測が成り立つ。 $A^{\prime}, C^{\prime}, U(z), \Theta^{\prime}(z)$ の関係を、内形火炎と同様に求 めると、下式が得られる。

$A^{\prime}=\chi \int_{0}^{\infty} \bar{q} d z / \Delta H c, O_{2} C\left[O_{2}\right] \int_{0}^{\infty} U(z) d z$

$C^{n} \cong \Delta H c, O_{2} C\left[O_{2}\right] \int_{0}^{\infty} U(z) d z / \rho C_{p} \chi \int_{0}^{\infty} U(z) \Theta^{\prime}(z) d z$

(9),(11)式と(15),(16)式を比較して、円形火炎と一方向火炎の性質 の違いを考察すると、C と $C^{\prime}$ の間には式の構成に本質的な違いは ないので、天井火炎の温度は火炎搪大の様相に大して影響されない と予想される。これに対して、A，A'の間では倸数が異なっている うえに、水平投影面積当たり発熱速度は一方向火炎の方が遙かに大 きいので、火炎厚さが一方向火炎の方が円形火炎より大きくなるか、 水平方向流速は、一方向火炎の方が円形火炎より十分大きくなると 予想できる。

ところで、火炎の巻き込み速度が一定でありながら、流れ方向流 速が火炎の始点からの距離に比例するという推測は、このように基 礎方程式の次元的構造を矛盾なく説明するが、乱流火炎への巻き込 み速度が火炎の軸上流速に比例するとする床上の火炎等について確 立された仮説とは全く異なっている。しかし、本実験で示したよう な天井面下の火炎では、火炎とその下方との間に重力方向に増加す る著しい密度勾配が生じるため、火炎下面と下方の空気との間の物 質交換は、噴流軸の静圧降下に由来する巻き込み(entrainment)より も、有風時の水面に生じるさざ波と同様に Kelvin-Helmholz 型不安 定による混合が卓越する可能性が大きく、天井面下の火炎について は既往の巻き込み理論がうまく適合しないとすれば、それは天井面 下の火炎と、浮力によって上昇する火炎との機構的な違いを表すも のと考えられる。今回の実験でも、また既報に示した一方向の天井 面火炎でも、火炎の伸縮が、自由空間や壁際の火炎に比べて明瞭で
なかったのは、その一つの反映であろう。

\section{5.天井面下と壁際の火炎長さの比較}

Figure 3 に見られる発熱速度と火炎面積の関係は、天井や庇の下 では火炎が伸びて、火炎長を短縮する効果はあまり期待できないと いう実験的所見 “支持するものである。例えば、線火源に対する 火炎長さと実効発熱量の関係を天井面と壁面とで比較すると、

天井面 ${ }^{10)} \quad \mathrm{L}_{\mathrm{i}}=0.023 \mathrm{Q}$,

壁面 ${ }^{12)} \quad \mathrm{L}_{\mathrm{i}}=0.06 \mathrm{Q}_{i}^{2 / 3}$

となるから、 $\mathrm{Q}_{l}>17.8 \mathrm{~kW} / \mathrm{m}$ では天井面下の火炎の方が壁面や床面 上の火炎よりも長くなり、 $\mathrm{Q}_{1}=142 \mathrm{~kW} / \mathrm{m}$ では天井面下の火炎長さ は壁面上のそれの 2 倍に達する。火災盛期の火炎室開口から噴出す る火炎が含む可然気体を発熱速度に換算すると、通常、これらより も大きい值になると考えられるから、庇が火炎の短縮に十分な効果 をあげないとみなされても不自然ではない。庇が上階延焼防止に顕 著な効果をあげるとす㧈ば、それは庇が火炎高さを短縮するからと いうよりは、単純に火炎が上階空面から遠ざかって空面が受ける放 射が低隇さ扎る場合であろう。

\section{6.まとめ}

本実験の結果から、天井燃焼による火炎性状について判明した事 実と分析を通じて推定できる諸関係をまとめると以下のようになる。 (1)天井火炎の面積は発熱速度に比例するが、単位面積当たり発熱速 度は一方向火炎の方が放射状に拡がる火炎より大きい。

(2)円形の天井火炎からの天井面入射熱は最大でも $30 \mathrm{~kW} / \mathrm{m}^{2}$ に達し ない。これは、一方向の天井火炎とほぼ同等であるが、壁面に 接する火炎からの表面入射熱よりも低く、単独では木質系天井 内装等で急速な火炎伝播を発生させるには不十分である。実際 の室火災や実大火災実験で観察さ扎る急速な天井面燃焼拡大に は、天井に着火する前の火源による予熱や煙層による天井面全 体の加熱も重要な役割を果たしていると推定される。

(3)天井火炎の火炎下側からの巻き込み空気量は、火炎のどの部分で もほぼ一様と推定できる。但し、火炎の天井面投影面積当り巻 き込み空気量は、円形火炎より一方向火炎の方が大きいと推定 される。

(4)天井火炎では、床上の火炎に比べて燃焼効率が著しく低下する。

(5)次元解析によると、火炎の拡がる方向の水平流速成分は、火源中 心からの距離に比例すると推定できる。更に、一方向火炎は、 円形火炎に比べて、水平流速が大きいか火炎厚さが大きくなる 亡予想される。

なお、天井火炎に関する実験報告は、その火災安全上の重要性に 比較していかにも例が少ない。本実験の測定内容も限られたもので あり、今後、更に多面的な研究が進められるように期待したい。本 実験の結果を踏まえて、天井火炎の性状とその火炎危険への影響の より定量的な把握を進める上で実験的に把握する価值があると思わ れる課題を提言して、本論文の結びにかえたい。

本研究では実験計画に含めるに至らなかった測定内容であるが、

（1）火炎内部の温度・流速(特に水平方向)のブロファイル、水平方 向距離毎の温度・流速最大値の変化の測定

（2）煙層が形成された状態での天井火炎の一般性状・天井面入射 


\section{熱の測定}

（3）燃焼生成物の分析

は、今後、天井火炎のモデル化を進める上で必要性が高いと考える。 その理由は次の通りである。

温度・流速分布の質的特徵については、本論文で次元的考察に基 づく推定を行ったが、ここではその実験的検証や数量的予測に必要 な諸定数の把握までが出来たわけではない。床上の火炎のモデル化 が流速や流量の詳細な測定を通じて高度に洗練されたことを考えれ ば、天井火炎でも、流速分布等が具体的に把握できれば、天井火炎 における燃焼反応機構の理解につながると期待できる。技術的に困 難かもしれないが、火炎の流量も直接測定できれば、巻き込み機構 の明確化に資するところが大きいであろう。また、煙層が形成され た状態での天井火炎性状を把握することができれば、可燃天井面の 火炎伝播における煙層からの予熱の効果や、一般の区画火災におけ る天井燃焼のように煙層内で酸素濃度が低下した状態での燃焼発熱 機構の明確化につながると期待できる。煙層を伴う状態での天井火 炎の実験では、煙層と天井火炎の状態をそれぞれ定常状態に保つこ とが望ましいが、その成否が実験の重要な課題となろう。本研究と

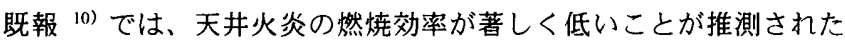
が、燃焼効率が低ければ CO 等の有害な中間生成物も多量に放出さ れる可能性がある。燃焼生成物の分析は、天井火炎における燃焼効 率の低下の原因解明を含む燃焼機構のより詳細な把握に必要なだけ でなく、天井燃焼の人命危険評価上の必要性も大きい。

なお、放射状に拡がる天井火炎の性状は、既報に示した一方向に 拡大する場合に比べて、気流等への外乱や装置の状態に遙かに敏感 で、実験も遙かに困難である。この両者の間には、空気の巻き込み と天井面加熱に系統的な差はあるが、火炎形成の機構に質的な違い があるわけではないことも判明したので、放射状に拡がる火炎に特 殊な問題を除けば、天井火炎の機構的な解明を更に進める実験的方 法としては、一方向火炎で研究する方が容易であろう。

\section{謝辞及び付記}

本研究の一部は科学研究費基盤研究(B)「局部火災加熱される構 造部材の加熱分布予測と部材温度応答計算法」の一環として実施し た。実験にあたっては東京理科大学大学院(当時)の高池良輔氏、藪 田孝敏氏、木村毅氏の参加を得、考察・論文作成の際には、早稲田 大学大学院の南東君氏の助力を得た。記して深甚の謝意を表します。

[注 1] 奏効発熱速度は、 $\mathrm{O}_{2}$ だけでなく、 $\mathrm{CO}_{2}, \mathrm{CO}$ の㵋度も使って計算した 方が测定精度が高まる。本実験では予借実験の段階で $\mathrm{O}_{2}$ 以外の测定系の出 力に異常が琹められたため $\mathrm{O}_{2}$ 濃度だけで発熱速度を求めたが、この方法で は $\mathrm{O}_{2}$ 濃度の減少は全て完全燃㚾に笴与したと仮定されるので、中間生成物 が発生して完全燃焼しなかった場合は発熱速度を過剩評価することになる。 従って、実効発熱速度をもっと高い精度で測定すれば、その值は更に低下し、 燃烧効率は本研究の報告値より低下する可能性がある。

[注 2]林上の火炎高さは火源の形状・寸法と発篤速度に支配されるが、発 熟速度が火源寸法に比べて十分大きければ発熱速度のみに支配される。本段 落の火炎高さは、このような条件に对し間歇火炎高さを公称発熱速度からや や過剩側で求める実験式 ${ }^{1 !)} 、 L=0.20 Q^{25}$ で算定した。

[注 3]この仮定は妥当なものと考えるが、(6),(7)式に関わる次元解析的考 察は、この仮定の成否とは関保なく成り立つものである。

\section{TERMINOLOGY}

$A, A^{\prime}, B, B^{\prime}, C, C^{\prime}:$ constants

$C$ ] : mass concentration( - )

$\mathrm{C}_{\mathrm{p}}$ : specific heat of air $(\mathrm{kJ} / \mathrm{kgK})$

$\Delta \mathrm{H}_{\mathrm{c} . \mathrm{O} 2}$ heat of combustion per unit mass of oxygen $\left(13.17 \times 10^{3} \mathrm{KJ} / \mathrm{kg}\right)$

$L_{f}$ : flame length, flame $\operatorname{radius}(\mathrm{m})$

$Q$ : heat release rate $(\mathrm{kW})$

g: gravitational acceleration $\left(\mathrm{m} / \mathrm{s}^{2}\right)$

$m, n$ : power constants

$p: \quad$ gauge pressure $(\mathrm{Pa})$

$q$ : heat release rate per unit volume $\left(\mathrm{kW} / \mathrm{m}^{3}\right)$

$q_{T}:$ total heat flux $\left(\mathrm{kW} / \mathrm{m}^{2}\right)$

$r: \quad$ radial distance $(m)$

u: $\mathrm{x}$-directional velocity in the Cartesian coordinate $(\mathrm{m} / \mathrm{s})$

$v$ : velocity component in the columnar coordinate $(\mathrm{m} / \mathrm{s})$

w: $z$-directional velocity in the Cartesian coordinate $(\mathrm{m} / \mathrm{s})$

$x$ : downstream horizontal distance in the Cartesian coordinate $(\mathrm{m})$

z. downward vertical distance $(m)$

$\beta$ : $\quad$ expansion coefficient $(1 / \mathrm{K})$

$\theta$ : excess temperature $(\mathrm{K})$

$\rho$ : density of $\operatorname{air}\left(\mathrm{kg} / \mathrm{m}^{3}\right.$

$\chi: \quad$ excess air ratio $(-)$

sufffix and other symbols

l: $\quad$ per unit width

$r$ radial direction

$z: \quad$ vertical direction(downward)

-: time averaging

: eddy fluctuation

\section{参考文献}

1)Babrauskas, V.Flame Lengths under Ceilings,Fire \& Materials,4,p119 126, 1980 2)You,H.Z., Faeth, G.M.: An Investigation of Fire Impingement on a Horizontal Ceiling, Report for NBS, 1979

3)Kokkala,M.A.: Experimental Study of Heat Transfer to Ceiling from an Impinging Diffusion Flame, Proceedings of the Third International Symposium on Fire Safety Science, Edinburgh, p261 270, 1991

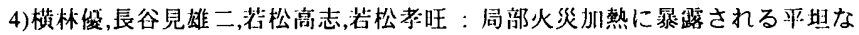

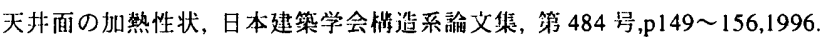
5)横井鎮男：スハンドレルは防火上どの位の商さが必要とされるか，火炎, 第 9 巻 2 号, p64 67, 1959.

6)佐藤博臣,鈴木健,栗岡均,閔沢愛,箭内英治,山田常圭：中高層建物の噴出火 炎性状に関する実験的倾究 その 3 写真等の画像記䟿を基にした火炎性 状の考察, 平成 11 年度日本火炎学会研究発表会概要集, p318～321,1999.

7)Thomas,P.H. : The Size of Flames from Natural Fires, Proceedings of the Ninth Symposium(Intn'l) on Combustion, Ithaca, p844 859, 1963.

8)横井鎮劦：炎の高さについて, 日本火炎学会論文集, 第 13 卷第 1 号, p22 $\sim 27,1963$

9)Zukoski,E.E., Kubota,T., Cetegen,B. : Entrainment in Fire Plumes, Fire Safety Journal, Vol.3, p107〜121, 1980/81.

10)横林優,長谷見雄二, 吉田正志,若松孝旺：天井燃接における火炎·熟気流 の加熱性状および火炎伝播性状，日本建築学会計画系諭文集，第 519 号, $\mathrm{pl} \sim 7,1999$.

11)McCaffrey,B.J. : Purely Buoyant Diffusion Flames: Some Experimental Results, NBSIR 79-1910, 1979

12)長谷見雄二：垂直面における上方火焔伝播の熱的モデル・I，日本建筑学 会構造系論文報告集，第359 号, p117〜 124, 1985 